\title{
THE IMPACT OF COVID-19 PANDEMIC: CHALLENGES AND OPPORTUNITIES OF SYARIAH FINANCIAL TECHNOLOGY
}

\author{
Ramadhani Irma Tripalupi \\ UIN Sunan Gunung Djati Bandung \\ ramadhaniirmatripalupi@uinsgd.ac.id \\ Prameshwara Anggahegari \\ School of Business and Management, Institut Teknologi Bandung \\ prameshwara@sbm-itb.ac.id
}

\begin{abstract}
This paper aims to describe the challenges and opportunities of syariah financial technology (fintech) in Indonesia, due to the impact of covid-19 pandemic. Three things that become the focus of writing, include: syariah fintech; the impact of covid-19 pandemic on fintech; syariah fintech opportunities and challenges. This study uses a qualitative approach and descriptive method with documentation/text studies in the form of related data and literature studies. The conclusion of this research is: the growth of Syariah fintech assets at the end of 2019 increased by $2074.81 \%$ from the previous year. Although affected by the pandemic, the growth of fintech during this covid-19 pandemic remained relatively stable. Prominent opportunities and challenges for the Syariah fintech resulting from the impact of covid-19 pandemic, including increased use of fintech through online shopping platforms, payments and loans; accelerated digitalization of financial services; slowed economic activity; arose various risks; and decreased debtor/UMKM performance due to the impact of the pandemic.
\end{abstract}

Keywords: covid-19; impact on fintech; syariah fintech opportunities and challenges.

\section{A. INTRODUCTION}

Financial technology (fintech) is increasingly developed along with the increase of sophisticated information and communication technology that penetrated into various aspects. Technological developments are able to support the changes of product innovation, services and business models in this fast-paced and efficient era, including of the financial sector both conventional and syariah. The advances of information and communication technology are able to support the needs of providing services and systems on the financial sector in the current digital era, one of which is known as fintech.

Fintech can be defined commonly as technological innovation in financial services. Service providers/financial services develop technology that can disrupt traditional financial markets by developing new technology-based applications that can be used for payments to more complex applications such as artificial intelligence and big data (Harahap et al., 2017)

In Indonesia, technology-based financial services or fintech have been increased rapidly since 2016, marked by the formation of the Indonesian Fintech Association (Aftech) which has been legally registered as a legal entity since March 10, 2016 (Harahap et al., 2017). Based on Indonesia Statistics, in the year of 2018 there will be 200 e-commerce services and 272 fintech companies. While based on October 2018 statistics from the Financial Services Authority (OJK) and Bank Indonesia (BI), there is around 194 fintech companies in Indonesia, consists of 127 companies (Peer to peer lending / P2P Lending (P2PL), 34 Digital 
Financial Innovations (IKD), 19 e Money Organizers, 11 Payment Gateway companies, and 2 e wallet companies.

Indonesia Muslim population in 2020 was estimated to reach 229.62 million people or approximately $87.2 \%$. This great potential for Syariah fintech was in line with the statement that delivered by the OJK that is encouraging the Syariah financial industry by digitizing and collaborating with fintech. According to the OJK note, syariah bank financing data as of June 2019 amounted to Rp 335.5 trillion, the value rose by $12.8 \%$ compared to last year in the same period. While BI recorded fintech financing as of June 2019 reaching Rp 8.3 trillion or grow by $274 \%$ compared to the same period from the previous year of Rp 2.2 trillion. Judging from the amount of financing, fintech is still smaller. But from its growth, fintech streaking high. This shows that fintech is a strategic opportunity for Syariah finance to increase market share.

In line with the statement from the National Syariah Council of the Indonesian Ulema Council (DSN MUI) that is to accelerate the increase in Syariah financial market share in Indonesia, cooperation is encouraged between financial technology companies and Syariah banking. Even DSN MUI has provided a strong foundation for developing Syariah fintech in Indonesia by issuing fatwa of syariah fintech in the form of Syariah fintech electronic money (e-money) and fatwa of fintech lending or financing.

Indonesian Financial Services Sector Master Plan (MPSJKI) 2020-2024 period which is a continuation of the previous period 2015-2019, had one of five areas that is the acceleration of digital transformation. The area was then reduced in the form of five OJK strategic policies in 2020, which related to this area include build a digital financial ecosystem in the financial services industry and fintech start-up, and accelerating efforts of digitize the financial services sector by facilitating licensing of digital-based financial products and services. This policy is expected to make the financial services sector more beneficial for Indonesia's economic growth and improving people's welfare. OJK was optimistic about this improvements on economic growth and positive financial service sector performance will continue in 2020. Banking intermediation performance is estimated to grow in the range of $11 \pm 1 \%$, with the low maintained risk level.

However, then there was a pandemic of Corona Virus Diseases 19 (covid-19) in the early 2020, which then affected the global economic and financial sectors. The spread of the covid-19 pandemic began in mainland China in early 2020, and became a pandemic outbreak that affected 214 countries with 3,349,786 cases as of May 4, 2020. Indonesia is one of the countries infected with this virus starting around midMarch 2020, and until May 42020 11,192 cases were recorded. In June 2020 the countries that were infected, most were still struggling to deal with this covid-19 pandemic.

It is predicted that various sectors such as trade performance, business activities, and exchange rates will decline dramatically, including the fintech industry. Aftech revealed that covid-19 pandemic had an impact on the performance of the fintech industry in Indonesia. According to the results of the survey in early April 2020 , approximately $68 \%$ of fintech organizers had a negative impact. Approximately $23.4 \%$ stated that business activities are still growing. This impact is particularly visible in the decline of productivity due to changes on operational patterns and increased risk of uncertainty in the market, decreased costumer demand, decreased number of transactions, and increased operational risk. Before the covid-19 pandemic occurred, in 2018, Indonesia fintech contributed Rp25.97 trillion on Gross Domestic Product (GDP) directly or indirectly and absorbed a workforce of 215,433 .

To anticipate the impact of covid-19 pandemic, the government issued an extraordinary policy to reduce the impact of covid-19 spread in Indonesia through the issuance of Government Regulation of Law substitution (Perppu) No. 1 of 2020 which was ratified in April 2020 concerning State Financial Policy and Financial System Stability for Handling Covid-19 Pandemic and / or in the Context of Facing Threats that Endanger 
the National Economy and / or Financial System Stability. Previously according to its authority, OJK issued a countercyclical policy for non-bank financial service institutions (LJKNB) through OJK Regulation (POJK) Number 11/POJK.03/2020 concerning National Economic Stimulus as a Countercyclical Policy on the Impact of Spreading Coronavirus Disease 2019. Then, OJK Number 14 / POJK.03/2020 concerning National Economic Stimulus as Countercyclical Policy on the Impact of Spreading Coronavirus Disease 2019. .05 / 2020 concerning Countercyclical Policy on the Impact of the 2019 Coronavirus Disease Spread for Non-Bank Financial Services Institutions. This is a part of several POJK that determined to support the means to maintain financial system stability and to encourage the wheels of the national economy to keep moving.

POJK does not accommodate fintech lending for restructuring due to the difference between fintech lending business model with banks and finance companies. However, Indonesian syariah Fintech Association (AFSI) as the fintech lending organizers association always supports government policies related to loan restructuring, and appealed to its members to actively participate to help and alleviate the fintech lending platform users affected by the covid-19 pandemic.

Covid-19 pandemic which originated from health problems is then impacts on various fields including the economic sector, then the financial sector, especially on bank and non-bank financial institutions, including fintech. There are various things and habits that change so fast that even as digital accelerates, so does people's behavior towards fintech. One example is when the social distancing policies are implemented, people start to learn, work and worship from home so that there is an increase in the use of digital financial services to support their activities. This is indicated by the increased sales on the online shopping platform by $30 \%$ and fintech payments and loans by $100 \%$ until May 2020 .

The existence of this pandemic shows that there are many potentials that still exist and even appear in the field of fintech, that then formulated to which will be the opportunities and challenges. Moreover, the government actively supports various policies and programs. This study aims to explain the opportunities and challenges of syariah fintech resulting from the impact of the covid-19 pandemic. The approach uses qualitative, descriptive methods with documentation / text studies in the form of related data and literature studies. This paper will discuss about the problem in three ways, including: 1) Fintech syariah; 2) The impact of the covid-19 pandemic on fintech; and 3) Syariah fintech opportunities and challenges.

\section{B. METHOD}

This study was conducted during the second to fifth month of covid-19 pandemic in Indonesia. The research uses a qualitative approach and descriptive methods, and developed using a literature review or literature study approach in the form of books, scientific journals and internet platform. Secondary data collection that was used came from related agencies such as: BI, OJK, Ministry of Finance, Ministry of Health, and various literatures. Considering that the material and related research are still inadequate, the writer will describe and analyze the results of the study and draw conclusions from the data sources and literature review.

\section{RESULTS AND DISCUSSION}

\section{Fintech Syariah}

In addition to the definition of fintech presented in the introduction, here are some other definitions. Fintech is a line of business based on using software to provide financial services, financial technology companies 
are generally startups founded with the purpose of disrupting incumbent financial systems and corporations that rely on software (Hadad, 2017)

Bank Indonesia Regulation (PBI) Number 19/12/PBI/2017 concerning Implementation of Financial Technology article 1, fintech is: 'the use of technology in the financial system that will produce new products, services, technology, and/or business models which can have an impact on monetary stability, financial system, and /or efficiency, continuity, security, and payment systems' reliability. Article 3 states that the operation of fintech is categorized into: (a) payment system (payments); (b) market provisioning; (c) investment management and risk management; (d) loans, financing and capital provision (P2PL and crowdfunding equity); (e) other financial services. There are currently two authorities in Indonesia that regulate fintech, that is $\mathrm{BI}$ which regulates fintech related to payments. Whereas OJK regulates fintech which provides financial services, such as: digital banking, P2PL loans, crowdfunding equity, insurance technology, investment and market aggregators (Batunanggar, 2019)

There are two main reasons for the emergence of fintech companies. First, the global financial crisis in 2008, where the cause of the crisis was the shortage of traditional banking systems. Secondly, the emergence of new technologies that support mobility, ease of use (visualization information), speed and cost of financial services that are lower (Saksonova \& Kuzmina-merlino, 2017). Fintech appears with the change in the lifestyle of people in the use of information technology or can be said to arise along with the digital era. On the other hand the demands of life that require all that fast-paced and efficient things turn the information technology that facilitates it to be needed by the community, such as fintech. With fintech some things can be simplified and can be minimized, including trade and payment transactions, since there is no time to look for goods, to go to the bank or ATM and so on. Fintech assists in transactions and payment systems that are more efficient but still effective.

In Indonesia, syariah fintech had been attracting public attention, as the establishment of AFSI in the year of 2018 that oversees syariah fintech in Indonesia. As well as the legalized Syariahh fintech as an economic transaction, and they also can be registered in OJK. The implementation of Syariah fintech in Indonesia getting attention from the Government along with the issuance of the related fatwa by DSN-MUI No. 117/DSN-MUI/II/2018 concerning information technology-based financing services that based on syariah principles (Hiyanti et al., 2019). The Fatwa was issued after the DSN-MUI No. 116/DSN$\mathrm{MUI} / \mathrm{I} / 2017$ that are concerning about electronic money (e money) Syariah. The contents of Fatwa DSNMUI No. 117/DSN-MUI/II/2018 are: the general guidelines of information technology-based financing services including the basic of Syariah, service model, mechanisms and contract. Departing from the fatwa, these are the understanding and model of the service of Syariah fintech.

Syariah Fintech is a digital financial technology or financial service based on syariah law sourced from Al Quran and Sunnah. Syariah fintech service currently found in financial services business. Syariah Fintech is a technology-based business with innovative financial services or products that had Syariah schemes, which use the syariah contract and principles to avoid things that were haram, bathil, syubhat, maysir and gharar. Andriawan (2018) asserted that there were three principles of Islam that must be followed by syariah fintech, which is prohibiting the Maysir (gambling), riba (the amount of interest that passed over provisions) and Gharar (uncertainty) (Aulia, et al, 2020)

Syariah fintech service model that can be done by the organizer are: factoring financing, financing of goods procurement by a third party (purchase order), financing goods procurement of the businesses who sell online based (online seller), financing goods procurement of the businesses who sell online based with payment through the provider of payment gateways, financing of employees, community based financing (community based), and digital payment instrument or electronic money (electronic money). 
Here are the reason behind the rapid growth of fintech in recent years. Firstly, the millennial indoor is accustomed to the Internet platform and the use of technology in various activities including financial services. Second, the more widespread use of smartphones, social media, and the Internet platform is encouraging people to make online transactions. Third, big data development that supports the implementation of fintech (Modalku, 2016). This is also implied by Currency Cloud (2015) projects that fintech will grow mostly in Asia, followed by Africa, North America, Latin America and Europe in the next two years (Amalia, et al, 2016).

According to the Indonesian statistics, in the year of 2018 , mobile phone users are about $133 \%$, while the Internet users are $56 \%$ and social media users are $56 \%$ of the population of 265 million. As for e Commerce Service are about 200 and fintech company as much as 272 company. As a comparison, in 2018 mobile phone users around the world were $67 \%$, the Internet amounted to $57 \%$ and social media $45 \%$ of the population of 7.676 billion. As of September 2019 the number of fintech actors in Indonesia is 272. Consisting of 172 lending, 72 payments, 35 market provision, 16 asset management, and 22 others.

Meanwhile based on data from OJK and $\mathrm{BI}$ in 2019, the number of participants in the funding fintech registered and licensed is about 164 paticipants, 152 of conventional perpetrators and 12 Syariah fintech. The increase in the amount of loans channeled $97.6 \%$ from the previous year with the proportions: $40 \%$ P2PL , 2\% Payments, 9\% Market Provisioning, 4\% Crowdfunding Equity, 4\% Wealth Management, 3\% Insurance, $4 \%$ Analytics \& Al, and $34 \%$ of others. As of December 2019, a conventional fintech financing asset of Rp 2.985 trillion rose $93.02 \%$ from the previous year. Syariah fintech assets reached nearly Rp 51 billion or $1.67 \%$ of total fintech assets, and the growth rose $2074.81 \%$ from the previous year. Judging from the share on the total assets of fintech funding in 2019, syariah fintech lagged far from conventional. But the growth rate is higher in syariah fintech. As of April 2020 a conventional financing fintech asset reaches Rp 3.564 trillion, Syariah fintech assets amounted to Rp 51 billion. This shows the growth remains stable during the pandemic.

\section{Impact of Pandemic Covid-19 on Fintech}

As conveyed by the finance minister that all sectors experience the impact of Covid-19 pandemic, the impact occurs like a domino effect. This pandemic was a health problem then impacted on the social field, the economic sector, and it will certainly affect the financial sector, especially on the bank and not bank financial institutions.

One of the financial sectors affected by Covid-19 pandemic is the fintech industry performance. As it has been mentioned above in early April 2020, approximately $68 \%$ of fintech organizers have a negative impact. Approximately $23.4 \%$ of business activities are still growing. These impacts are particularly noticeable in the decreased productivity due to changes in operational patterns as well as increased risk of uncertainty in the market, declined consumer demand, decreased transaction counts, and increased operational risk. For fintech industry P2PL, the survey results of the Indonesian Joint Funding Fintech Association (AFPI) of 130 members (from 161 fintech lending consisting of 12 Syariah fintech and 149 conventional fintech) until 6 April 2020 , there are as many as 68 platforms or approximately $52 \%$ stated that they have been given a restructuring request from the loan applicant (borrower). Another declined financial performance is the success rate of 90 days loan repayment, In February 2020 to $96.08 \%$ dropped from $96.35 \%$ two months earlier, or dropped about $98.55 \%$ from December 2018.

The increase imbalance of the borrower's demand and economic strength of the investor may due to the slowing of economic activity when Covid-19 pandemic has begun to be perceived as a reaction in February 
(Mukhlisin, 2020). The slowing of economic activities also affected UMKM performance, which has also made fintech the source of their funding. As of June 2020 the portfolio of credit for UMKM in national banking and financing industry that covers $20-25 \%$. Meanwhile, according to business practitioners, the problem faced by UMKM is capitalization and this can be addressed by fintech.

On the other hand, the enactment of Study From Home (SFH) and Working From Home (WFH) during the Covid-19 pandemic, resulting on more people that are using internet technology. The technology is used for various purposes such as education, preaching, occupation or entertainment (Mukhlisin, 2020). As also seen from the report (Deloitte, 2020), the social distancing policy suggests that there is tremendous growth in the use of digital finance and e-commerce services. This creates opportunities for fintech.

Arner's study (2020) suggests that a crisis is not a time to try to implement a completely new technology and digital solution. This is the time to use an existing digital infrastructure for greater things and the onset of new potential. Social distancing policies may change people's habits. These changes can be measured by seeing a significant surge of e-commerce activity,ho me entertainment such as streaming platforms, delivery services, digital financial services, and payment platforms. Covid-19 pandemic affects people's behaviour against various online and digital services. Once the crisis is resolved, it is likely that the habit such as cost savings and costumer comfort factors because of the service, will result in permanent behavioral changes (Arner, 2020).

Sales over the online shopping platform In Indonesia as of May 2020 increased by $30 \%$ and fintech payments as well as lending disbursement jumped by $100 \%$. Meanwhile the data on the statistic fintech lending according to OJK until April 2020 shows that the lender's transactions increased by $36.07 \%$, and the borrower transactions increased by $53.65 \%$.

\section{Syariah Fintech opportunities and challenges}

Most business activities will face some market opportunities and challenges. The opportunities and challenges of syariah fintech which is the result of Telkom Indonesia study (2017) is as follow, the opportunities include (Djawahir, 2018): (1) The majority of Indonesian are Muslims and 64\% of them are still unbanked, thus potentially increase the number of prospective syariah fintech users. (2) Syariah economic is in growth. (3) Syariah economic and syariah fintech are supported by an established technology. (4) Syariah fintech regulation is still in the cultivation stage, thus creating opportunities to innovate through syariah fintech. The challenge of Syariah Fintech markets include: (1) Lack of awareness and public knowledge of syariah finance, especially syariah fintech. (2) The economic growth of Syariah is slow and the market share is still small compared to the conventional one. (3) The qualified human resources in syariah economic field are still lacking. (4) The poor synergies between syariah financial institutions with social institutions engaged in the economic field of people, such as the institutions zakat and Waqf.

The opportunities and challenges of Indonesia syariah fintech according to a research by Hiyanti et al (2019), are as follows; The opportunities including: (1) OJK provides an opportunity for syariah fintech practitioners to register formally in OJK; (2) The ease of technology to carry out investment activities and donations; (3) The existence of conventional fintech cases and phenomena that occur in the community; (4) The majority of Indonesian Muslims are currently more than 207 million; (5) The opportunities for the inclusion of technological developments in Indonesia are still available. The challenges including: (1) The minimum Syariah fintech licensing and capitalizing, thus only 4 companies that have been registered in OJK; (2) The Lack of village community knowledge to operate syariah fintech; (3) The public assumption that there is no difference between syariah fintech and conventional fintech; (4) Lack of human resources to control the transaction agreement based on syariah principles; (5) Technological competition in the future. 
Batunanggar (2019), in his research suggests that Indonesia has many opportunities in the digital economy, include: its economic size, population, as well as the number of Internet users and mobile phones. And there are two main challenges, include: low level of financial inclusion and financing of micro, small and medium enterprises (UMKM) (Batunanggar, 2019). Meanwhile, based on Aulia et al research, it suggests that fintech has the potential to bring about major changes in Islamic finance industry through cost effectiveness, process efficiency and financial inclusion (Aulia, 2020).

Mukhlisin (2020) explained in his article, that this pandemic is the right momentum to encourage people and policymakers to analyze more about the syariah aspects of fintech. Ranging from contract, terms and conditions, law harmonization, tax administration, accounting, as well as auditing. The article also shows the expected opportunities and challenges of syariah fintech development during the Covid-19 pandemic. The opportunity includes: (1) Improve Syariah's economic and financial literacy to be more active. (2) To bring demands and offers to UMKM. (3) Achieve pro growth and pro poor. (4) Improving Indonesian family work ethic. Due to the advances in technology, syariah fintech is able to reduce waiting time, road traffic and the transaction queues. As for the challenge, includes: (1) The slow pace of International and Indonesia economy will have a negative impact on UMKM established by the fintech. (2) The increase risk of technological crimes caused by reduced family income.

As noted above, according to Arner (2020), a crisis is not a time to try to implement new technology and digital solutions entirely, but it is a time to use existing digital infrastructures for greater things and new potentials. Thus the programs are tailored to the current conditions, reformulating the potentials, which one are the opportunities and challenges. It is then realized in the latest activity to maintain or even increase the performance. Moreover, financial services have been facilitated by the Government with various policies that support them.

Based on several previous studies, Covid-19 pandemic researchs, and various data sources, the authors tried to compile the opportunities and challenges of syariah fintech during this pandemic. Those opportunities include:

(1) Syariah Fintech has the potential to grow, this can be seen from:

(a) The user convenience due to the cost effectiveness and the efficiency of process/time, this is because consumers are more frugal on expenditure/cost and time. this is in accordance with what was conveyed by Mukhlisin (2020) above, resulting in the increase of work ethic.

(b) 229.62 million of Indonesia residents are Muslims and 64\% of them are still unbanked, thus they are potentially become the user of syariah fintech.

(c) The number of mobile and internet users, even in 2019 , each increased by $19 \%$ and $13 \%$ from the previous year.

(d) The growth of fintech payments and syariah fintech assets of funding.

(2) The increase of digital financial services (fintech) use through: Online shopping platforms by $30 \%$ and payments as well as loans each increased by $100 \%$ due to the impact of SFH and WFH. The growth of fintech funding before the pandemic amounted to be $75 \%$, in which in 2019 the increase in the loan amount channeled was $97.6 \%$ from the previous year with the total financing fintech assets amounting to Rp 3.306 trillion. As of April 2020 fintech financing assets increased by $9.35 \%$ from the end of 2019 , the total reached Rp 3.615 trillion. Even the growth of Syariah fintech assets increased by $2074.81 \%$ from the previous year. This shows that the growth in the pandemic is still relatively stable. So they still has the potential to increase the on going syariah financial market share approximately 5-6\%.

(3) The acceleration of financial services digitalization. Any situations and conditions encountered during the pandemic, ultimately encouraged the perpetrators/providers and users to accelerate the 
digitalization of financial services. Thus, they also supported the Master Plan of the Indonesian Financial services sector (MPSJKI) in the period of 2020-2024.

(4) Supporting technology for accelerating digitalization of financial services.

(5) UMKM Financing. One of the problem of UMKM is capitalization, so fintech is an alternative source of funding because it is more efficient.

(6) The government support prior to the pandemic in the form of regulations for syariah fintech including DSN MUI, as well as OJK's current policy of a relatively new pandemic that had a positive impact on the financial sector, thus creating opportunities to innovate through syariah fintech.

Meanwhile, the challenges include:

(1) The delayed economic activity which is an impact of a pandemic. Peoples that stay at home because SFH and WFH, resulting on the declined consumption and business or trade activities. This causes the decreased production capacity or even the termination of employment (PHK), thereby causing a decline in community income. The decreased community income will encourage people to revise their priority spending scale. Another cause of the economic ups and downs is the declined exports and imports.

(2) The various risks for business perpetrators due to a pandemic, such as: market uncertainty, declined demand, operational risk and the risk of success rate of return, as well as the risk of a request for restructuring.

(3) The declined performance of UMKM. The survey stated that $96 \%$ of UMKM perpetrators have to undergo the negative impacts of this covid-19 pandemic on their business. $75 \%$ of them experienced a significant decrease in sales.

(4) The low levels of financial literacy and inclusion, especially the syariah fintech. this is especially true in rural areas that have not mastered technology yet, as Mukhlisin (2020) pointed out. Financial literacy and inclusion will give the contribution to financial system stability and new market potential.

(5) The lack of competent human resources in syariah economic field. These human resources are needed to play a central role in accelerating the digitalization of financial services.

\section{CONCLUSIONS}

Syariah fintech in Indonesia has started to attract a lot of attention in 2018. As of September 2019, the number of registered and licensed fintech funders is 164, include 152 conventional perpretators and 12 syariah fintechs. The fintech assets of conventional funding as of December 2019 amounted to Rp 2.985 trillion, increased by $93.02 \%$ from the previous year. Syariah fintech assets reached approximately to Rp. 51 billion or $1.67 \%$ of total fintech assets, but the growth increased by $2074.81 \%$ from the previous year. As of April 2020 syariah fintech assets are still around Rp. 51 billion.

The impact of covid-19 pandemic as of April 2020 on fintech is, that approximately $68 \%$ of fintech organizers had a negative impact and $23.4 \%$ of business activity are still growing. Those impacts are particularly visible in the declined productivity due to changes in operational patterns and increased risk of uncertainty in the market, decreased consumer demand, and increased operational risk. There are as many as 68 platforms or approximately $52 \%$ of them who explained that they had received a request for restructuring from the debtor. On the other hand, the online shopping platforms sales as of May 2020 increased by $30 \%$ and fintech payments as well as loans jumped to $100 \%$. The growth of total funding for fintech assets in 2019 was Rp3,306 trillion. As of April 2020 fintech funding assets increased by $9.35 \%$ from 
the end of 2019, totaling Rp3.615 trillion. This is showed that despite being affected by the pandemic, the growth of fintech during covid-19 pandemic remain relatively stable.

The opportunities and challenges of syariah fintech during this pandemic include, opportunities: (1) Syariah fintech has the potential to grow, in terms of: the cost effectiveness and process efficiency; the potential population which is predominantly Muslim and 64\% unbanked; the number of mobile and internet users; and the growth of fintech payments and funding assets. (2). Increased use of digital financial services (fintech) through: online shopping platforms, payments and loans (funding). (3) Acceleration of financial services digitalization. (4) Technology that supports acceleration of financial services digitalization (5) UMKM financing. (6) The government support. The challenge includes: (1) The delayed economic activity. (2) The occurrence of various risks due to pandemic, such as: market uncertainty, declined demand, operational risk and risk of return rate as well as risk of restructuring request. (3) Decreased UMKM performances and other debtors that are the impact of pandemic. (4) Low levels of literacy and financial inclusion, especially syariah fintech. (5) The lack of competent human resources in the field of Syariah economics.

\section{REFERENCES}

Arner, Douglas W., Barberis, JN, Walker, J, Buckley, RP, Dahdal, AM, Zetzsche, D. 2020. Digital Finance \& the COVID-19 Crisis. SSRN Paper Series. Accessed from https://ssrn.com/ on $2^{\text {nd }}$ of June, 2020.

Amalia, F., Chishti, S., \& Barberis, J. (2016). Book Review : the fintech book : the financial technology handbook for investors, entrepreneurs and visionaries. 31(3), 345-348.

Aulia, M., Yustiardhi, A. F., \& Permatasari, R. O. (2020). Jurnal Ekononomi \& Keuangan Islam. 6(1), 64-75. https://doi.org/10.20885/JEKI.vol6.iss1.art7

Batunanggar, S. (2019). Fintech development and Asian Development Bank Institute. 1014.

Chishti, Susanne and Barberis, Janos. 2016. The Fintech Book: The Financial Technology Handbook for Investors, Entrepreneurs and Visionaries. United Kingdom: John Wiley \& Sons Ltd, West Sussex. ISBN 978-1-119-21887-6.

Deloitte. 2020. Beyond COVID-19: New Opportunities for Fintech Companies. Deloitte Center for Financial Services. Accessed from http://www.deloitte.com/us/cfs on 2nd of June 2020.

Djawahir, Abdillah Ubaidi. 2018. Teknologi-Layanan Keuangan, Literasi-Inklusi Keuangan, dan Value pada Fintech Syariah Di Indonesia: Perspektif S-O-R (Stimulus-Organism-Response) Model. Artikel Proceedings 2nd Annual Conference for Muslim Scholars. Accessed on $7^{\text {th }}$ of November 2019.

Hadad, M. D., \& Ph, D. (2017). Financial Technology ( FinTech ) di Indonesia. Accessed fromhttp://www.scribd.com on $9^{\text {th }}$ of September, 2018.

Harahap, B. A., Idham, P. B., M, A. C., Rakhman, R. N., Harahap, B. A., Idham, P. B., M, A. C., \& Rakhman, R. N. (2017). Working paper perkembangan financial technology terkait central bank digital currency ( cbdc ) terhadap transmisi kebijakan moneter dan makroekonomi Perkembangan Financial Technology terkait Central Bank Digital Currency ( CBDC ) terhadap Transmisi Kebijakan Moneter dan Makroekonomi. 0-80.

Hiyanti, H., Nugroho, L., Sukmadilaga, C., Fitrijanti, T., Buana, U. M., \& Syariah, F. (2019). Jurnal Ilmiah Ekonomi Islam , 5 ( 03 ), 2019 , 326-333 Peluang dan Tantangan Fintech ( Financial Technology ) Syariah di Indonesia. 5(03), 326-333.

Keuangan, T., \& Djawahir, A. U. (n.d.). Keuangan, dan value pada fintech syariah di indonesia : Perspektif S-O-R ( Stimulus-Organism-Response ) Model. April 2018, 439-448.

Mukhlisin, Murniati. 2020. FinTech Syariah di Indonesia dan Pandemi Covid-19. Accessed from https://sharianews.com/ on $13^{\text {th }}$ of June 2020 
Ozili, Peterson K. (2020). Financial Inclusion and Fintech during COVID-19 Crisis: Policy Solutions. Jurnal Elektronik SSRN. Desember 2020. Accessed from https://www.researchgate.net/ on $2^{\text {nd }}$ of June, 2020.

Saksonova, S., \& Kuzmina-merlino, I. (2017). Fintech as Financial Innovation - The Possibilities and Problems of Implementation. XX(3), 961-973.

Online Resources:

www.ojk.go.id/id/kanal/iknb/data-dan-statistik/fintech/default.aspx Accessed on 2nd of June, 2018

republika.co.id/berita/qdgt5p383/tiga-dampak-besar-pandemi-covid19-bagi-ekonomi-ri Accessed on 2nd of June, 2018

https://mediaindonesia.com/read/detail/299778-7-jurus-agar-ekonomi-ri-selamat-dari-covid-19

keuangan.kontan.co.id/news/sekitar-68-anggota-asosiasi-fintech-terimbas-dampak-negatif-corona Accessed on 2nd of June, 2018

https://www.aa.com.tr/id/ekonomi/asosiasi-fintech-perkuat-kerja-sama-inklusi-keuangan-saat-covid19/1840770 Accessed on 2nd of June, 2018

finansial.bisnis.com/read/20200516/90/1241384/apakah-kebijakan-ojk-sudah-mampu-memperkuat-duniausaha-dan-perbankan Accessed on 2nd of June, 2018

kominfo.go.id/content/detail/6119/syarat-sertifikasi-startup-e-commercedihapus/0/sorotan_media

katadata.co.id/desysetyowati/digital/5ebe683c3f41d/menkominfo-startup-e-commerce-kesehatan-fintechmoncer-saat-pandemi Accessed on 2nd of June, 2018

keuangan.kontan.co.id/news/upaya-modalku-antisipasi-dampak-covid-19-ke-bisnis-p2p-lending

www.liputan6.com/bisnis/read/4233426/ojk-minta-fintech-beri-keringanan-kredit-bagi-debitur-terdampakcorona Accessed on 2nd of June, 2018

www.cnnindonesia.com/ekonomi/20181109210344-81-345386/beda-cara-bisnis-bank-multifinance-danfintech-pinjaman Accessed on 2nd of June, 2018

katadata.co.id/yuliawati/digital/5e9a56310b01d/beda-dengan-bank-dana-kelola-fintech-akan-dibatasi-olehojk Accessed on 2nd of June, 2018 